\title{
Impact of Sugar Industrial Treated Effluent on the Growth Factor in Sugarcane-Cuddalore, India
}

\author{
Usha Damodharan, M. Vikram Reddy ${ }^{*}$ \\ Department of Ecology and Environmental Sciences, Pondicherry Central University, Pondicherry, India \\ Email: *Venkateshsrinivas1@gmail.com, ${ }^{*}$ prof.mvikramreddy@yahoo.com, ushadamodhar@gmail.com
}

Received May 7, 2012; revised June 10, 2012; accepted June 17, 2012

\begin{abstract}
The present study focused on evaluating the impact of application of sugar industry treated wastewater effluent on Sugarcane growth comparing at two experimental farms, one irrigated with the effluent and the other with bore well water, over a period of 11 months (March 2010 to January 2011).The result indicated a significant increase in growth pattern, plant height, shoot diameter, number of leaves and nodes, and biomass of the saplings that was irrigated with the effluents compared to that irrigated with bore well water. The growth parameters showed close relationship with the nutrient contents of treated industrial effluent and bore well water, the former being characterized by relatively higher $\mathrm{pH}$, electrical conductivity $(\mu \mathrm{s} / \mathrm{cm})$, total suspended solids (TSS), sulphate, biochemical oxygen demand, chemical oxygen demand, nitrate and phosphate, and heavy metals - $\mathrm{Cu}, \mathrm{Pb}, \mathrm{Cd}, \mathrm{Zn}$ and $\mathrm{Mn}(\mathrm{mg} / \mathrm{l})$ compared to that of bore well water, indicating profound influence of nutrient rich sugar industry effluent on the plant growth. Higher biomass in sugarcane saplings resulted with irrigation of the effluents compared to that irrigated with the bore well water.
\end{abstract}

Keywords: Industrial Effluent Irrigation; Bore Well Water Irrigation; Sugarcane; Growth Pattern; Biomass

\section{Introduction}

Emerging trends of agricultural automation, and reclaimed and treated industrial effluent irrigation over stresses the agricultural land resources through their excessive micro element contamination [1]. Rising trends of using the waste water (industrial effluents) for irrigation has the advantage of pollution removal where the pollutants are partly taken up by the plants and partly transformed in the soil without causing any damage. In many parts of the world, treated effluents have been successfully used for irrigation, and researchers have recognized its benefits [2]. In the Mediterranean countries, treated wastewater is increasingly used in the areas with water scarcity, and its application in agriculture is becoming important to water supplies. The potential for adverse health impacts of irrigation with wastewater has been addressed in a number of earlier studies. Effective and appropriate wastewater treatment processes can reduce the health hazards associated with wastewater use. However, [3] the treated effluent coming through stabilization ponds or conventional treatment plants followed by maturation ponds or sand filtration may be free of pathogens. In India as referred by [4], the significant positive correlation between the growth of the saplings

"Corresponding author.
Casuarina equisetifolia and the nutrient quality of municipal sewage has been reported. In Greece, the possibility of wastewater reuse for irrigation of vegetables has been studied by Kalavrouziotis [5]. Several earlier studies have shown the advantages and disadvantages of using wastewater for irrigation of various crops. The reuse of treated wastewater is a good option for increasing water supplies to agriculture. One of its benefits is the plant's use of the water's nutrients and therefore, a reduction in the pollution load that wastewater contributes to the water and land resources [6]. However, depending upon its sources and treatments, industrial wastewater may contain high concentrations of nutrients and toxic heavy metals and the reclaimed industrial wastewater application may create undesirable effects in soils, which may lead to bio-accumulation in plants and pose a health risk for human beings.

In effluent-fed agriculture, nutrients flow from wastewater into the plants accelerates and improves the crop production, and eventually it may lead to the reclamation of effluent water as an added advantage. Many economically important vegetables and flowering plants can utilize the major nutrients $\left(\mathrm{NO}_{3}-\mathrm{N}, \mathrm{NH}_{4}-\mathrm{N}\right.$ and $\mathrm{H}_{2} \mathrm{PO}_{4} /$ $\mathrm{HPO}_{4}-\mathrm{P}$ ) for their growth from the nutrient-rich waste water upon proper management or suitable amendments [7]. This concept may be applied as a method for eco- 
logical treatment of wastewater but there is also a risk of accumulation of the heavy metals within the edible parts of the plant that can create metal toxicity in the human body when they are consumed. This accumulation depends directly upon the concentration of heavy metal in wastewater, so the feasibility of implementing this ecotech for wastewater reclamation massively must be cautioned of heavy-metal accumulation in leaf and crops. Several drawbacks in using waste water for agriculture was determined [6]. They reported the problem of soil salinity, interaction of chemical constituents of the wastes with the uptake of nutrients and changes in soil property and micro flora in the agricultural field irrigated with the wastewater. This necessitates a detailed study before any specific waste can be used for irrigation for a particular crop with a particular soil and climate. The objective of this research work was to study the effects of sugar industry treated effluent reuse for the irrigation of sugarcane crop, comparing two sources of irrigated water and evaluating their effects on plant growth. Since, crop plants are increasingly being irrigated with the effluents, an attempt has been made to study the comparative effects of sugar industry treated effluents and bore well water on growth and biomass in sugarcane.

\section{Materials and Methods}

\subsection{Sampling Location}

The experimental sites were located in Cuddalore and Panruti both from Cuddalore district, Tamil Nadu. The first experimental plot was located at Nesanur in Cuddalore, where the treated wastewater used and the second experimental plot was located at L.N.Puram in Panruti where the bore well water was used for irrigating sugar- cane. Sampling at Nesanur farm and Panruti farm was undertaken across 5 plots each measures approximately $50 \mathrm{~m} \times 200 \mathrm{~m}$ and sugarcanes of these plots were measured every month for their length, shoot diameter, number of leaves and nodes (Figure 1).

\subsection{Irrigation and Fertilization}

Flood irrigation method was followed for irrigating both the sugarcane fields. Effluent Irrigation was scheduled at two months interval and the bore well water irrigation was scheduled at six or ten days interval. The actual irrigation application rate may be altered in response to rainfall, soil moisture, and other related factors. An average of $128 \mathrm{~kg} / \mathrm{ha} \mathrm{N}, 63 \mathrm{~kg} / \mathrm{ha} \mathrm{P}_{2} \mathrm{O}_{5}$ and $7 \mathrm{~kg} / \mathrm{ha} \mathrm{K}_{2} \mathrm{O}$ fertilizers were applied in both the fields.

\subsection{Physico-Chemical and Heavy-Metal Analysis}

The physico-chemical characteristics $-\mathrm{pH}$, electrical conductivity $(\mu \mathrm{s} / \mathrm{cm})$, total suspended solids, 5-days biochemical oxygen demand, chemical oxygen demand, nitrate nitrogen, sulfate, phosphate $(\mathrm{mg} / \mathrm{l})$ and heavy metals - $\mathrm{Cu}, \mathrm{Pb}, \mathrm{Cd}, \mathrm{Zn}$ and $\mathrm{Mn}(\mathrm{mg} / \mathrm{l})$ of sugar industry treated effluent and bore well water were analyzed using following standard methods cited in Table 1 [8]. Water analysis was done taking three replicates.

\subsection{Plant Growth Measurement}

The heights, diameter of shoots and number of nodes and leaves, of each sugarcane sapling in each replicate plot were recorded every month, and the biomass of each of the saplings was measured at the end (12 months) of the experiment (Table 1).

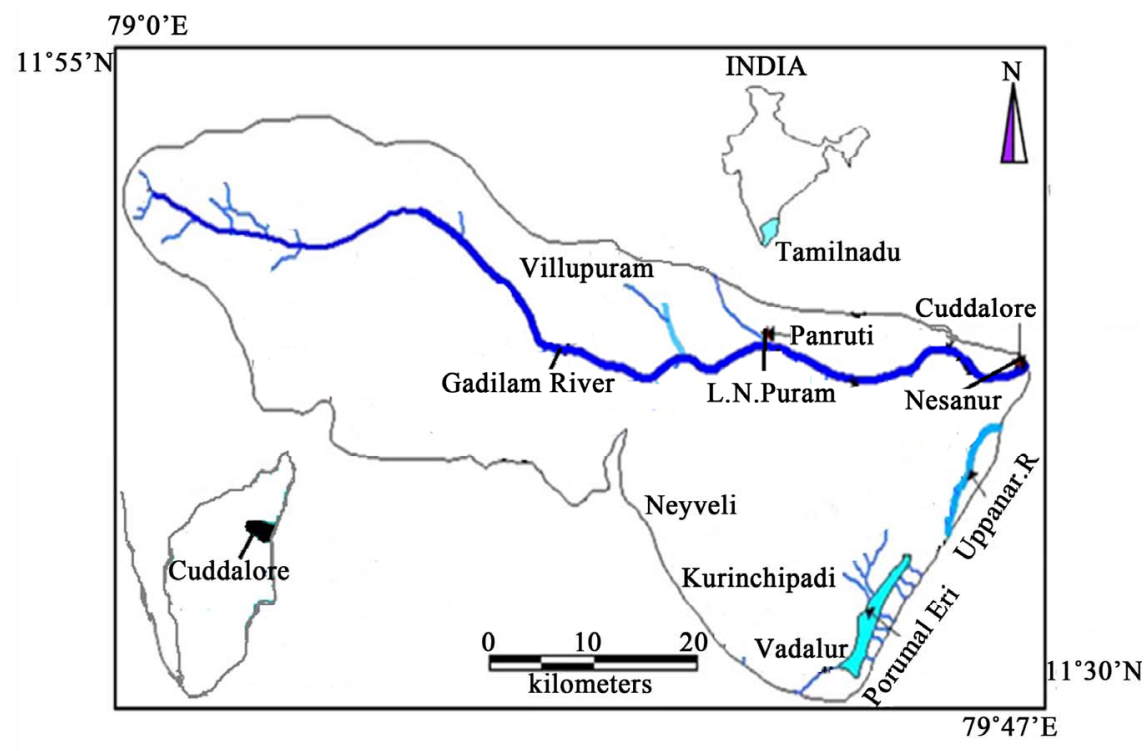

Figure 1. Sampling locations. 
Table 1. Methods for measuring different parameters used in this study.

\begin{tabular}{cc}
\hline Parameters & Methods \\
\hline $\begin{array}{c}\text { Stem length and diameter } \\
\text { Number of nodes and leaves } \\
\text { Biomass } \\
\text { Sulfate }\end{array}$ & $\begin{array}{c}\text { Simple scale measuring method } \\
\text { Visual counting method } \\
\text { Wet weight measuring method }\end{array}$ \\
PO $_{4}-\mathrm{P}$ & Spectrophotometric method (APHA, 1995) \\
$\mathrm{NO}_{3}$ - & Stannous chloride method (APHA, 1995) \\
Temperature & Spectrophotometric screening method (APHA, 1995) \\
pH & Partial immersion method (APHA, 1995) \\
Chemical oxygen demand & Electrometric method (APHA, 1995) \\
Biological oxygen demand 5-day dilution & Closed reflux titrimetric method (APHA, 1995) \\
Total suspended solid (TSS) & BOD test method (APHA, 1995) \\
Digestion of heavy metals (Cd, $\mathrm{Cu}, \mathrm{Pb}, \mathrm{Zn}$ and $\mathrm{Mn})$ & Filtration and thermal evaporation method (APHA, 1995) \\
Estimation of heavy metals (Cd, $\mathrm{Cu}, \mathrm{Pb}, \mathrm{Zn}$ and $\mathrm{Mn})$ & Di-acid digestion method (APHA, 1995) \\
\hline
\end{tabular}

\subsection{Statistical Analysis}

ANOVA analysis of the data on height of the saplings, diameter of shoots, number of nodes and leaves of plants that were grown in industry treated effluent and bore well water over the 11 month period was computed. Multiple correlation analyses were computed between the nutrients of the irrigated water and the plant growth.

\section{Results}

\subsection{Water-Quality Parameters}

Analyses of water quality parameters such as $\mathrm{pH}$, electrical conductivity, suspended solids (TSS), Biochemical Oxygen Demand-5, Chemical oxygen demand, nitrate nitrogen, sulfate, phosphate $(\mathrm{mg} / \mathrm{l})$ and heavy metals $(\mathrm{Cu}$, $\mathrm{Pb}, \mathrm{Cd}, \mathrm{Zn}$ and $\mathrm{Mn}$ ) of sugar industry treated effluent and bore well water used for irrigation of sugarcane saplings showed that the average concentrations of each of the above water quality parameters of treated effluent were higher than those of the bore well water (Table 1). The average temperature in the treated effluent and bore well water were $28.1^{\circ} \mathrm{C}$ and $27.0^{\circ} \mathrm{C}$, respectively. The average $\mathrm{pH}$ and that of electrical conductivity and nitrates $(\mathrm{mg} / \mathrm{l})$ in treated effluent were higher than those of the bore well water. The average TSS, BOD, phosphates, nitrates and sulfates in treated effluent were 108, 3100, 35,7 and 23 folds higher than that of the bore well water, respectively (Table 2). The COD of treated effluent water was higher $(19,860 \pm 247.85 \mathrm{mg} / \mathrm{l})$ while its concentration was below the detection limit in bore well water indicating its cleanliness. Heavy metals like $\mathrm{Cu}, \mathrm{Pb}, \mathrm{Zn}$ and $\mathrm{Mn}(\mathrm{mg} / \mathrm{l})$ in treated effluent were 150, 48, 352 and 83 folds higher than the bore well water, respectively
(Table 2).

\subsection{Sugarcane Sapling Growth}

One of the ways to reduce the pollution of the receiving water bodies due to the industrial effluent is its optimum reuse in irrigation of crops and tree plantations. Our study revealed that the height of sugarcane during the first month of the irrigation with treated effluent and bore well water were $14.25 \pm 2.45$ and $9.12 \pm 1.54 \mathrm{~cm}$, respectively. After four months of irrigation, the height of the saplings increased $41.4 \pm 12.68$ and $38.5 \pm 18.37 \mathrm{~cm}$, respectively, whereas after eight months the height of the saplings increased to $148.12 \pm 37.17$ and $92.18 \pm 14.68$ $\mathrm{cm}$ in treated effluent and bore well water irrigation, respectively; after eleven months of irrigation and at the time of harvesting the height of the saplings recorded were $185.15 \pm 34.12$ and $135.12 \pm 21.15 \mathrm{~cm}$, respectively in the two corresponding sites (Figure 2). ANOVA results of the plant height grown across the treatments of treated

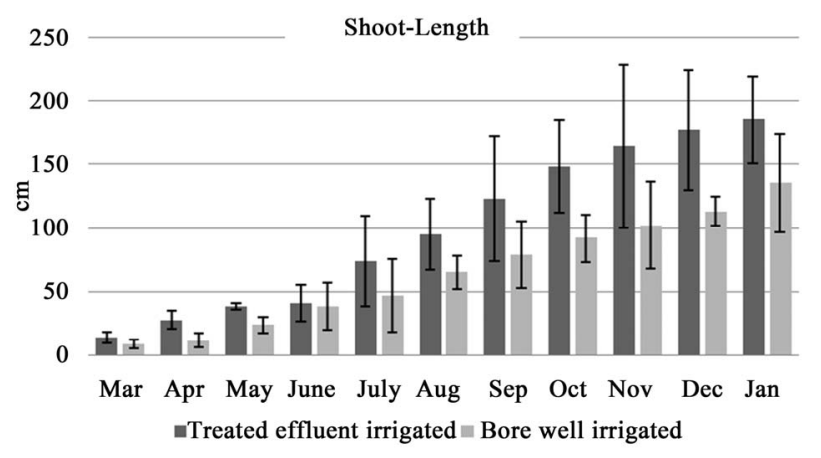

Figure 2. Variation in the shoot-length of the sugarcane across the two different treatments. 
Table 2. Mean concentration of physico-chemical parameters, and heavy metal concentration of treated effluent in relation that of bore well water used for irrigation.

\begin{tabular}{ccc}
\hline Physico-chemical parameters & $\begin{array}{r}\text { Treated } \\
\text { effluent }\end{array}$ & Bore well water \\
\hline Temp $\left({ }^{\circ} \mathrm{C}\right)$ & 28.1 & 27 \\
$\mathrm{pH}$ & 8.5 & 6.5 \\
$\mathrm{EC}(\mu \mathrm{s} / \mathrm{cm})$ & 1076 & 164 \\
$\mathrm{TSS}(\mathrm{mg} / \mathrm{l})$ & 432 & 4 \\
$\mathrm{COD}(\mathrm{mg} / \mathrm{l})$ & 19,860 & $\mathrm{BDL}$ \\
$\mathrm{BOD}(\mathrm{mg} / \mathrm{l})$ & 9300 & 3 \\
$\mathrm{Nitrate} \mathrm{(mg/l)}$ & 36.7 & 5 \\
$\mathrm{Phosphate}(\mathrm{mg} / \mathrm{l})$ & 14 & 0.39 \\
$\mathrm{Sulfate}(\mathrm{mg} / \mathrm{l})$ & 107 & 4.53 \\
$\mathrm{Heavy}$ & & \\
$\mathrm{Cu}(\mathrm{mg} / \mathrm{l})$ & 3.12 & 0.02 \\
$\mathrm{~Pb}(\mathrm{mg} / \mathrm{l})$ & 1.46 & 0.03 \\
$\mathrm{Cd}(\mathrm{mg} / \mathrm{l})$ & 2.37 & $\mathrm{BDL}$ \\
$\mathrm{Zn}(\mathrm{mg} / \mathrm{l})$ & 14.11 & 0.04 \\
$\mathrm{Mn}(\mathrm{mg} / \mathrm{l})$ & 5.03 & 0.06 \\
\hline
\end{tabular}

effluent and bore well water being recorded highest in the former and lowest in the later showed significant difference in the height of the saplings between and within the two sites (Table 3). There was significant positive correlation between the height of the saplings and the quality of treated effluent in the present study $(\mathrm{R} 2=0.74$, $\mathrm{p}<0.01$ ). Shoot length increased with the increase of strength of effluent. The lower height in the saplings irrigated with bore well water were most probably due to its relatively low nutrient contents.

Our present result showed that shoot diameter during the first month of irrigation with the treated effluent and bore well water were $5.13 \pm 1.1$ and $2.14 \pm 0.056 \mathrm{~cm}$, respectively. After fourth month of irrigation, it increased to $11.23 \pm 2.11$ and $7.09 \pm 3.45 \mathrm{~cm}$, respectively. After eight months of irrigation with the treated effluent and bore well water the diameter of the shoot increased to $15.26 \pm 4.13$ and $9.38 \pm 1.54 \mathrm{~cm}$, respectively and at the time of harvesting it was $22.34 \pm 9.75$ and $11.66 \pm 3.48$ $\mathrm{cm}$, respectively (Figure 3 ). In order to compare the variation in the numbers of leaves and nodes that indicate the physiological age of sugarcane plants irrigated with treated effluent and bore well water, were counted. ANOVA Analysis showed that the variations in their count between the two sites were significantly different (Table 3). The number of nodes of plants irrigated with the treated effluent ranged from $(2-23)$, whereas in the bore well water irrigated field it ranged from $(2-17)$. The node number was directly proportional to the strength of the effluent and it was declined in the bore well water irrigation (Figure 4). The number of leaf was more with the increasing strength of wastewater and the variances in number in relation to different strengths of effluent were statistically distinct (one way ANOVA, $\mathrm{p}<0.05$ ). The range of leaves of sugarcane irrigated with treated effluent were (2 - 36), and in the bore well irrigated field it ranged from (2 - 22) (Figure 5). Similarly, the average wet biomass of each sapling after 11 months of irrigation of treated effluent and bore well water were 4.3 and 2.85 $\mathrm{kg}$ per sapling, respectively (Figure 6).

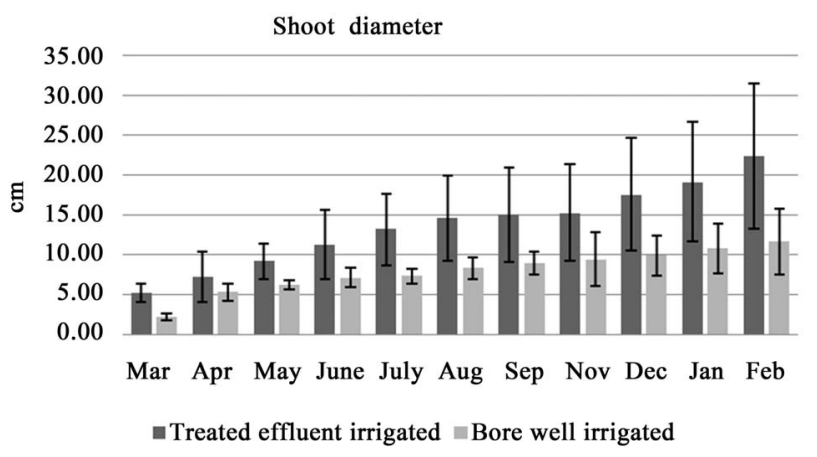

Figure 3. Variation in the shoot diameter of the sugarcane across the two different treatments.

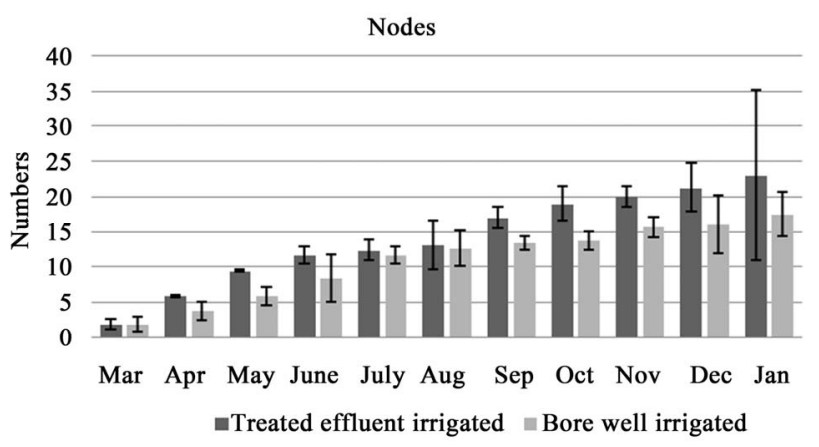

Figure 4. Variation in the number of the nodes of sugarcane across the two different treatments.

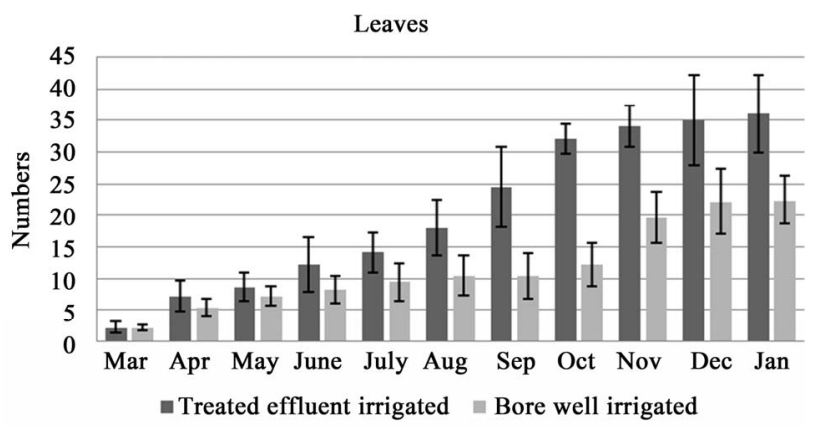

Figure 5. Variation in the number of leaves of the sugarcane across the two different treatments. 
Table 3. ANOVA analysis of growth of the plants (sugarcane) across two different irrigation treatments.

\begin{tabular}{|c|c|c|c|c|c|c|}
\hline Source of variation & SS & df & MS & $\mathrm{F}$ & p-value & F crit \\
\hline Height of the plants & 3599.522 & 11 & 3599.522 & 4.662467 & $0.033824^{*}$ & 3.960352 \\
\hline Diameter of the plants & 179.9512 & 11 & 179.9512 & 10.52694 & $0.004061^{*}$ & 4.351243 \\
\hline Number of nodes & 3309.183 & 13 & 1103.061 & 11.428797 & $2.74 \mathrm{E}-14^{* *}$ & 2.718785 \\
\hline Number of leaves & 404.6328 & 13 & 404.6328 & 4.921508 & $0.048642^{*}$ & 4.351243 \\
\hline
\end{tabular}

${ }^{*} \mathrm{p}<0.05,{ }^{* *} \mathrm{p}<0.01$.

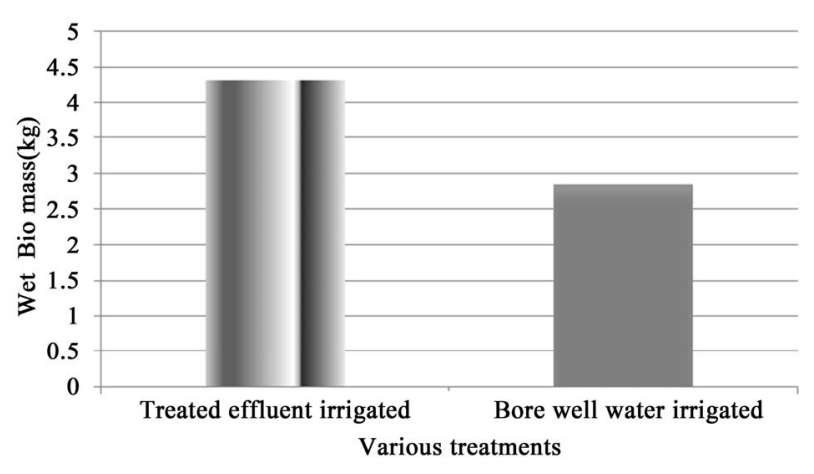

Figure 6. Variation of the wet biomass $(\mathrm{kg})$ of the sugarcane across different treatments.

\section{Discussion}

During the present investigation, a pattern of $\mathrm{pH}$ and temperature alteration was noticed in both the treated effluent and bore well water; the maximum value of $\mathrm{pH}$, indicated the alkaline nature of water, and it is attributed to high temperature that reduces the solubility of $\mathrm{CO}_{2}$. Due to the higher concentration of phosphates, sulfates, nitrates and other organic matters in the treated effluent showed a highest average value of total suspended solids, when compared to that of bore well water. In consistence to the present findings, [9] reported an increased physicochemical concentration in treated wastewater than that of ground water used for irrigation in Egypt. Similarly, [10] reported increased average values of the water-quality parameters-TSS, TDS, BOD, COD, $\mathrm{pH}, \mathrm{NH}_{3}$, phosphates, temperature $\left({ }^{\circ} \mathrm{C}\right)$ in treated effluents than that of river water in Kuwait.

Increased growth of sugarcanes irrigated with treated effluent is associated with the availability of increased organic matter, and both macro and micronutrients, especially total and available $\mathrm{N}$ in the treated effluent [11]. In consistence to the present findings, [12], also reported increased growth density and shoot length in Navel Orange trees irrigated with sewage in Egypt. Similarly, increase in water and nutrient availability through effluent application influenced the growth of Acacia nilotica [13]. [14] reported that nitrate in waste water is usually beneficial in increasing yields and quality. However, he also concluded that highest concentration of nitrate also can reduce the sugar content of crops, which may affect fla- vor and quality. Similar findings were also reported by [15], in green leafy vegetables. Delayed growth reported during the primary stage of the sugarcane sapling was agreed in the previous studies [16]. [17] reported that higher concentration of effluent causes delayed shoot growth, seedling growth and chlorophyll content in sunflower (Helianthus annuus) and it could be safely used for irrigation purpose at low concentration. However, presence of higher concentration of heavy metals in irrigated water has been reported to cause adverse effects in plants [18]. Maximum number of nodes and leaves reported in effluent irrigated sugarcane is probably due to the higher concentration of phosphate in effluent water, which is absorbed by the plant and stored for its metabolic process. [19] reported the significant increase in the sapling height in the treatment irrigated with municipal raw sewage in the species of Casuarina glauca, Eucalyptus camaldulensis and Tamarix aphylla. The availability of water and nutrients probably had positive effects on shoot growth [13]. Maximum biomass resulted in sugarcane saplings irrigated with treated effluent may be due to its response to the nutritive elements, constant supply and continuous replenishments of nutrients like nitrogen and phosphorous from irrigated water and improved soil structure. [13] reported higher growth and biomass in seedling of acacia and eucalyptus respectively, which they attributed to the effects of available nutrients, particularly $\mathrm{N}$ in the effluent facilitating leaf initiation that converted more solar energy enhancing $\mathrm{CO}_{2}$ fixation and photosynthetic level leading to higher growth and biomass production. The irrigation with effluent on landscape and agricultural fields has the risk of modified soil chemical and physical properties [11].

\section{Conclusion}

The findings from this study suggest that the irrigation with the treated sugar industry effluent characterized by high nutritive value can improve the overall growth of the sugarcane compared to the bore well water. Furthermore, irrigation with treated effluent minimizes the use of mixed compound chemical fertilizers, increases the soil organic matter, improves soil physical and chemical properties, upgrade soil fertility, and it is helpful for 
building good soil ecosystem and sustainable sugarcane production. These findings conclude that the future perspective of treated effluent in agriculture is favorable due to its effect on increased crop yield and growth, but there is also a possible accumulation of various nutrients and heavy metals in soil and in the ground water that may cause potential problems after long-term reclaimed wastewater irrigation. Nevertheless, it is suggested that risk assessment should be conducted prior to effluent irrigation to keep the safe application of wastewater for landscape and agriculture and make its reuse safer.

\section{Acknowledgements}

Mrs. Usha is very grateful to Ecology and Environmental Science Department of Pondicherry Central University for providing the laboratory facilities to carry out the necessary analysis, and to Pondicherry University for providing the university fellowship. This paper is a part of the primary author (Mrs. Usha)'s PhD research work.

\section{REFERENCES}

[1] F. A. Adekola, N. Salami and K. A. Lawai, "Assesment of the Bioaccumulation Capacity of Scots Pine (PinusSylvestris L) Neddles for Zinc, Cadmium and Sulphur in Ilorin and Ibadan Cities (Nigeria)," Nigerian Journal of Pure and Applied Science, Vol. 17, 2002, pp. 1297-1301.

[2] F. A. Adekola, N. Salami and S. O. Lawai, "Some Trace Elements Determination in Surface Water and Sediments of Oyunriver, Kwara State, Nigeria," Nigerian Journal of Pure and Applied Science, Vol. 18, No. 3, 2003, pp. 14181422.

[3] R. G. Feachem, D. J. Bradleg, H. Garslick and D. D. Mara, "Sanitation and Diseases-Health Aspects of Excreta and Waste Water Management," John Wiley \& Sons, Chichester, 1983.

[4] A. Y. Kumar and M. V. Reddy, "Effects of Municipal Sewage on the Growth Performance of Casuarina Equisetifolia (Forst. \& Forst.) on Sandy Soil of East Coast at Kalpakkam (Tamil Nadu, India)," Applied Ecology and Environmental Research, Vol. 8, No. 1, 2010, pp. 77-85.

[5] I. K. Kalavrouziotis and P. Koukoulakis, "Elemental Antagonism in Vegetables under Treated Municipal Wastewater," Journal of Plant Interactions, Vol. 5, No. 2, 2010, pp. 101-109. doi:10.1080/17429140903438092

[6] P. K. Goel and S. M. Kulkarni, "Effects of Sugar Factory Waste on Germination of Gram Seed (Ciceraeritinum L.)," International Journal of Environment and Pollution, Vol. 1, No. 1, 1994, pp. 35-53.

[7] S. Rana, S. K. Bag, D. Golder, S. Mukherjee (Roy), C. Pradhan and B. B. Jana, "Reclamation of Municipal Domestic Waste Water by Aquaponics of Tomato Plants," Ecological Engineering, Vol. 3, No. 2, 2011, pp. 175178.
[8] APHA, "Standard Methods for the Examination of Water and Wastewater (19th Edition)," District of Columbia American Public Health Association, Washington DC, 1995.

[9] A. F. EL-Gohary, A. Fayza Nasr and S. EL-Hawaary, "Performance Assessment of a Wastewater Treatment Plant Producing Effluent for Irrigation in Egypt," The Environmentalist, Vol. 18, No. 2, 1998, pp. 87-93. doi:10.1023/A:1006618307270

[10] M. A. Jasem, S. B. Haider and H. A. Tamamah, "Wastewater Reuse Practices in Kuwait," The Environmentalist, Vol. 23, No. 2, 2003, pp. 117-126. doi:10.1023/A:1024831503569

[11] K. B. Kandiah, "The Use of Municipal Waste Water for Forest and Tree Irrigation-Unasylya," Food and Agriculture Organization, Vol. 185, 1996, p. 9.

[12] M. S. Omran, T. M. Waly, E. M. A. Elnaim and B. M. B. El Nashar, "Effect of Sewage Irrigation on Yield, Tree Components and Heavy Metals Accumulation in Navel Orange Trees," Biological Waste, Vol. 23, No. 1, 1988, pp. 17-24. doi:10.1016/0269-7483(88)90041-9

[13] Singh, A. Bhati, R. K. Sharma, M. Agrawal and F. Marshall, "Effects of Wastewater Irrigation on Physicochemical Properties of Soil and Availability of Heavy Metals in Soil and Vegetables," Communications in Soil Science and Plant Analysis, Vol. 40, No. 21-22, 2004, pp. 3469-3490. doi:10.1080/00103620903327543

[14] M. B. Kirkham, "Problems of Using Wastewater on Vegetable Crops," Horticultural Science, Vol. 21, No. 1, 1986, pp. 24-27.

[15] S. Ramana, A. K. Biswas, S. Kundu, J. K. Saha and B. R. Yadava, "Effect of Distillery Effluent on Seed Germination in Some Vegetable Crops," Bioresource Technology, Vol. 82, No. 3, 2001, pp. 273-275. doi:10.1016/S0960-8524(01)00184-5

[16] M. Kuntal, M. Hati, K. B. Ashish, K. Bandyapadhyaya and K. Misra, "Effect of Post-Methanation Effluent on Soil Physical Properties under Soyabean-Wheat System in a Vertisol," Journal of Plant Nutrition and Soil Science, Vol. 167, No. 5, 2004, pp. 584-590. doi:10.1002/jpln.200321284

[17] K. P. Raverkar, S. Ramana, A. B. Singh, A. K. Biswas and S. Kundu, "Impact of Post Methanated Spentwash (PMS) on the Nursery Rising, Biological Parameters of Glyricidia sepum and Biological Activity of Soil," Annual Review of Plant Research, Vol. 2, No. 2, 2000, pp. 161-168.

[18] W. L. Berry, A. Wallace and O. R. Lunt, "Utilization of Municipal Wastewater for Culture of Horticultural Crops," Horticultural Science, Vol. 15, No. 2, 1980, pp. 169-171.

[19] M. H. El-Lakany, "Urban and Pert-Urban Forestry in the Near East Region: A Case Study of Cairo," Paper Prepared for the FAO Forestry Department, Unpublished Data, 1995. 